\title{
Antidiarrhoeal effect of the crude methanol extract of the dried fruit of Adansonia digitata L. (Malvaceae)
}

\author{
Mohammed Musa Suleiman ${ }^{1}$, Mohammed Mamman ${ }^{1}$, Ibrahim Hassan ${ }^{1}$, Shamsu Garba ${ }^{1}$, \\ Mohammed Umaru Kawu ${ }^{2}$ and Patricia Ishaku Kobo ${ }^{1}$
}

1. Department of Pharmacology and Toxicology, Faculty of Veterinary Medicine, Ahmadu Bello University, Zaria, Nigeria; 2. Department of Physiology, Faculty of Veterinary Medicine, Ahmadu Bello University, Zaria, Nigeria.

Corresponding author: Mohammed Musa Suleiman, email:mohsulai@yahoo.com

MM: mammanm@hotmail.com, IH: abusa001@gmail.com, SG: sdanjuma74@gmail.com, MUK: mukawa@yahoo.com, PIK: patriciakobo@yahoo.com

Received: 06-04-2014, Revised: 12-06-2014, Accepted: 14-06-2014, Published online: 19-07-2014

doi: 10.14202/vetworld.2014.495-500

How to cite this article: Suleiman MM, Mamman M, Hassan I, Garba S, Kawu MU and Kobo PI (2014) Antidiarrhoeal effect of the crude methanol extract of the dried fruit of Adansonia digitata L. (Malvaceae), Veterinary World 7(7): 495-500.

\begin{abstract}
Aim: The study was designed to evaluate the antidiarrhoeal property of the methanol extract of the fruit of Adansonia digitata using laboratory animal models.

Materials and Methods: The acute oral toxicity $\left(\mathrm{LD}_{50}\right)$ of the extract was determined in mice, while the antidiarrhoeal effect of different doses of the extract was evaluated in both mice and rats. The effect of the extract at doses of 300,700 and 1000 $\mathrm{mg} / \mathrm{kg}$ were tested against intestinal transit time, magnesium sulphate-induced gastrointestinal motility test and castor oilinduced diarrhoea in mice. Similarly, the extract at the doses mentioned above was evaluated against castor-oil induced enteropooling in rats.

Results: The methanol extract of $A$. digitata was shown to have no toxic effect in mice at doses up to $5000 \mathrm{mg} / \mathrm{kg}$. At doses of 300 and $700 \mathrm{mg} / \mathrm{kg}$ the extract significantly $(\mathrm{p}<0.01)$ decrease intestinal transit time in mice. In addition, the extract at doses of 300,700 and $1000 \mathrm{mg} / \mathrm{kg}$, significantly $(\mathrm{p}<0.05)$ lowered diarrhoea induced by magnesium sulphate and castor oil in mice. Similarly, the extract produced a significant $(\mathrm{p}<0.05)$ inhibition of enteropooling caused by castor oil in rats. The antidiarrhoeal effect of the extract was shown to be dose-dependent.

Conclusion: These findings revealed the potential of the extract of fruit of $A$. digitata as an antidiarrhoeal agent. The detailed mechanism of the extract antidiarrhoeal action is yet to be ascertained. However, one or more of the phytoconstituents contained in the extract could be responsible for the observed antidiarrhoeal effect.
\end{abstract}

Keywords: Adansonia digitata L., antidiarrhoeal activity, castor oil, charcoal meal, mice.

\section{Introduction}

Diarrhoeal disease is a potential cause of morbidity and mortality especially in children and young animals in the developing countries [1]. Traditional medicinal plants are widely employed in most developing countries for treating diarrhoea [2]. Treatment of diarrhoea is generally non-specific and usually aimed at reducing the discomfort and inconvenience of frequent bowel movements [3]. Most modern antidiarrhoeal agents are beyond the reach of the common man in developing countries. In addition, they have some levels of toxic effect $[4,5]$. To overcome the menace of diarrhoeal disease in developing countries, the World Health Organization (WHO) has included a programme for the control of diarrhoea, which involves the use of traditional herbal medicine [6].

Adansonia digitata L. (Malvaceae), popularly called baobab tree is widely distributed in hot savannah regions of sub-Saharan Africa. In India, powdered leaves are used to reduce excessive perspiration. The fruit is used internally with butter milk to manage cases

Copyright: The authors. This article is an open access article licensed under the terms of the Creative Commons Attribution License (http://creativecommons.org/licenses/by/2.0) which permits unrestricted use, distribution and reproduction in any medium, provided the work is properly cited. of diarrhoea and dysentery. The efficacy of $A$. digitata on microbial infection had been demonstrated [7]. The plant has a variety of medicinal uses which have been well documented [8]. In Nigeria, the plant is found mostly in the northern part of the country. Aqueous extract prepared from the bark of the plant is used in Nigerian traditional medicine for the treatment of fever [9]. The aqueous extract of the stem-bark of Adansonia digitata produced a significant chemosuppressive effect against Plasmodium berghei infection in mice [10]. The powder obtained from the fruit of the plant is used traditionally to treat dysentery and diarrhoea in Nigeria [11].

The present study was aimed at investigating the potential antidiarrhoeal effect of the fruit of $A$. digitata $L$. in in vitro and in vivo model.

\section{Materials and Methods}

Ethical approval: All experimental protocols described in this study were approved by the Ethics Review Committee for Animal Experimentation of Ahmadu Bello University, Zaria (U05VM10341087).

Plant collection, identification and processing: The dried fruits of $A$. digitata were purchased from a local market in Zaria (Samaru), Nigeria and were identified 
and authenticated in the Department of Biological Sciences, Ahmadu Bello University, Zaria, Nigeria. A voucher specimen number 2512 was deposited. The dried fruit was separated from the seed by gentle manual squeezing and made into fine powder. The powdered fruit $(200 \mathrm{~g})$ was cold extracted using methanol (600 $\mathrm{ml}$ ) in a separating funnel. The mixture was left to stand for $48 \mathrm{~h}$ before decanting the liquid extract. The process was repeated using $300 \mathrm{ml}$ of fresh methanol and allowed to stand for $24 \mathrm{~h}$ before decantation. The liquid extracts were pooled and concentrated into a brownwaxy residue.

Phytochemical analysis: The methanol extract of the A. digitata was subjected to phytochemical screening tests to detect the presence of carbohydrates, anthraquinones, flavonoids, tannins, alkaloids, saponins, glycosides, sterols and triterpenes [12].

Experimental animals: Adult Swiss albino mice of both sexes weighing about $18-22 \mathrm{~g}$ and albino rats weighing between 150-180 g were used for the study. The Animals were sourced from the Animal House, Department of Pharmacology and Therapeutics, Ahmadu Bello University, Zaria, Nigeria. The animals were housed in locally constructed cages and kept under room temperature. All animals were preconditioned in the laboratory for two weeks before the commencement of the experiment. Wood shavings were used as beddings in the animal cages and changed once every week. Animals were allowed free access to standard feed and water ad-libitum. The animals were kept at an ambient temperature of $25{ }^{\circ} \mathrm{C}$ and relative humidity of $70-80 \%$ with $12 \mathrm{~h} /$ day light period.

Safety evaluation: The method of Lorke [13] was used to determine the median lethal dose $\left(\mathrm{LD}_{50}\right)$ of the extract. In the first part of the trial, 9 Swiss albino mice were randomly allocated into three groups of three mice each. The animals were deprived of food for $24 \mathrm{~h}$ and water for $12 \mathrm{~h}$. Groups 1,2 , and 3 received the extract at 10,100 and $1000 \mathrm{mg} / \mathrm{kg}$ body weight, respectively. Mice were observed for signs of toxicity or mortality for $48 \mathrm{~h}$. The second part of the trial involved the use of 3 mice which were randomly allocated into 3 groups of 1 animal each. Mice in groups 1,2,3 were given the extract at 1600, 2900 and $5000 \mathrm{mg} / \mathrm{kg}$, respectively, and observed as described earlier.

Intestinal transit time in mice: Twenty five mice were randomly distributed into five groups of five mice each. Animals were denied feed for $24 \mathrm{~h}$ but allowed free access to water before the start of the experiment. Mice in groups 1,2 and 3 received the extract orally at 300,700 and $1000 \mathrm{mg} / \mathrm{kg}$ body weight, respectively. Animals in groups 4 and 5 received loperamide (1 $\mathrm{mg} / \mathrm{kg})$ and normal saline $(5 \mathrm{ml} / \mathrm{kg})$, respectively. All treatments were given per os. One hour after treatment, each mouse was given $1 \mathrm{ml}$ of $5 \%$ charcoal meal in $2 \%$ carboxymethycellulose orally [14]. An h after the charcoal meal was administered, all the mice were sacrificed in a closed chamber with the aid of chloroform. Mice were placed on dorsal recumbency on a dissecting board and a ventral mid-line incision was made on their abdomens, the intestines were exteriorized and carefully removed from the cardia to the ileocaecal junction. The intestines were immediately immersed in formalin to stop peristalsis and subsequently washed carefully using clean tap water to clearly see the intestinal contents. The distance traversed by the charcoal meal in each mouse was measured using a graduated ruler.

Magnesium sulphate-induced gastrointestinal motility test: Mice were divided at random into five groups of 5 mice each. All mice were deprived of food for $24 \mathrm{~h}$ before the experiment. Group 1 (untreated control) was given normal saline $(5 \mathrm{ml} / \mathrm{kg}$ ), while group 2 (treated control) received loperamide $(1 \mathrm{mg} / \mathrm{kg})$. Groups 3,4 and 5 were administered with the extract of $A$. digitata at 300,700 and $1000 \mathrm{mg} / \mathrm{kg}$, respectively. All treatments were given per os. After 30 minutes, each mouse received magnesium sulphate $(2 \mathrm{~g} / \mathrm{kg})$ by oral route [15]. The animals were placed individually in cages over white filter paper. The number of wet faeces was recorded for a period of $6 \mathrm{~h}$.

Diarrhoea induced by castor oil in mice: Twenty five mice were randomly assigned to five groups of five mice each. Before the start of the experiment all mice were fasted for $24 \mathrm{~h}$. Animals in groups 1, 2, and 3 were dosed orally with the extract at 300, 700 and 1000 $\mathrm{mg} / \mathrm{kg}$, respectively. Animals in group 4 and 5 received through oral route, loperamide $(1 \mathrm{mg} / \mathrm{kg})$ and normal saline $(5 \mathrm{ml} / \mathrm{kg})$, respectively. One h after treatment, all animals were given $5 \mathrm{ml} / \mathrm{kg}$ body weight of castor oil by mouth. Mice in each group were kept in individual cages whose floor was covered with a clean white paper. Faeces were collected on the paper for $8 \mathrm{~h}$ and the severity of diarrhoea in each group was graded as follows: Grade 0 (normal pelleted faeces), Grade 1 (discrete soft-formed faeces), Grade 2 (soft-formed faeces), Grade 3 (soft watery stool) and Grade 4 (watery stool) [16]. The diarrhoeal index was calculated by multiplying the number of mice in each grade by the number of grade divided by the number of mice in each group.

Effect of A. digitata on Castor oil-induced enteropooling: Intraluminal fluid accumulation was determined by method described by Robert et al [17]. Rats were at divided at random into five groups of five animals each, Groups 1 and 2 were given normal saline $(5 \mathrm{ml} / \mathrm{kg})$ and loperamide $(1 \mathrm{mg} / \mathrm{kg})$ and served as nontreated and treated control animals, respectively. Animals in groups 3, 4 and 5 received the extract at 300,700 and $1000 \mathrm{mg} / \mathrm{kg}$, respectively. All treatments were administered orally. One $\mathrm{h}$ after the administration of normal saline, loperamide and extract, $2 \mathrm{ml}$ of castor oil was given to each rat. Two hours after castor oil administration, the rats were sacrificed and the small intestine from the pylorus to the caecum was 


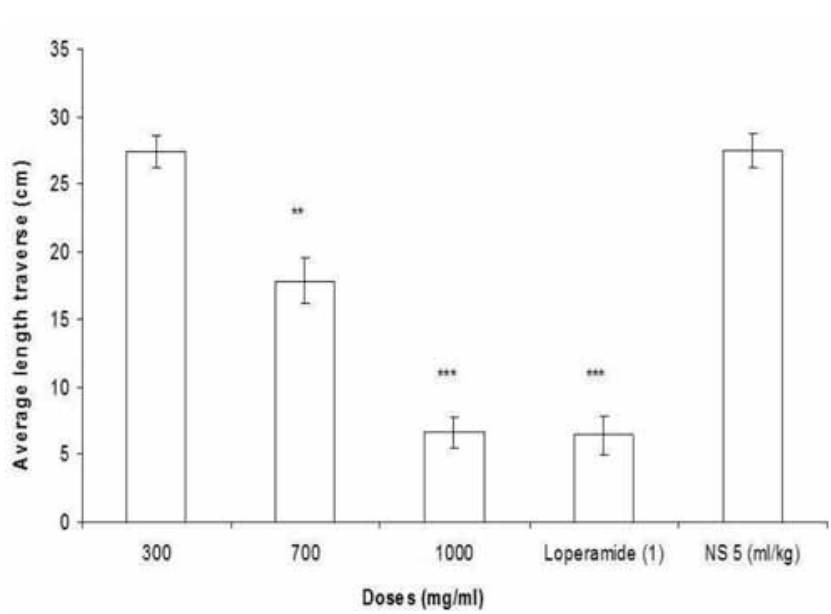

Figure-1: The effect of different doses of the extract of Adansonia digitata on gastro-intestinal transit time of mice. Mice in the non-treated group were given normal saline ( 5 $\mathrm{ml} / \mathrm{kg}$ ). Values are mean \pm S.E.M $* * * \mathrm{p}<0.001, * * \mathrm{p}<0.01$ and $* \mathrm{p}<0.05$ showed significant difference when compared with non-treated (normal saline) control group.

Table-1: Effect of the extract of Adansonia digitata on magnesium sulphate-induced diarrhoea in mice $(n=5)$.

\begin{tabular}{lccc}
\hline Treatment & Dose $(\mathrm{mg} / \mathrm{kg})$ (oral) & Number of wet faecal droppings (mean \pm S.E.M.) & \% inhibition \\
\hline Normal saline & $5 \mathrm{ml} / \mathrm{kg}$ & $24.40 \pm 2.10^{\mathrm{c}}$ & - \\
Loperamide & 5 & $6.2 \pm 1.30^{\mathrm{a}}$ & 74.59 \\
A. digitata & 300 & $15.60 \pm 1.60^{\mathrm{b}}$ & 36.07 \\
A. digitata & 700 & $10.40 \pm 0.93^{\mathrm{a}, \mathrm{b}}$ & 57.38 \\
A. digitata & 1000 & $8.20 \pm 1.20^{\mathrm{a}}$ & 66.39 \\
\hline
\end{tabular}

Means with different superscript letters differ significantly $(p<0.05)$ isolated. The content of the intestines from each rat was collected in a graduated glass tube and the volume measured.

Statistical analysis: Values obtained were expressed as mean \pm S.E.M and then subjected to one-way analysis of variance (ANOVA) followed by Tukey's post-hoc test using Graphpad Prism version 4.0 for Windows from Graphpad software, San Diego, California, USA. Values were considered significant if $p<0.05$.

\section{Results}

Extract yield: The plant gave a yield of $23.6 \%$ of the dried crude extract. fruit of $A$. digitata tested positive for carbohydrate, glycosides, saponins, flavonoids, tannins, steroids and triterpenes.

Acute toxicity test: The extract did not produce any mortality or apparent toxic signs when tested at doses of between 10 to $5000 \mathrm{mg} / \mathrm{kg}$.

Effect of A. digitata on intestinal transit: The extract at doses of 700 and $1000 \mathrm{mg} / \mathrm{kg}$ significantly $(\mathrm{p}<0.01)$ decreased intestinal transit time in mice (Figure-1).

Magnesium sulphate-induced gastrointestinal motility test: The extract at doses of 700 and 1000 $\mathrm{mg} / \mathrm{kg}$ and loperamide $(5 \mathrm{mg} / \mathrm{kg})$ significantly $(\mathrm{p}<$ 0.001 ) inhibited the frequency of defaecation relative
Phytochemical tests: The methanol extract of dried

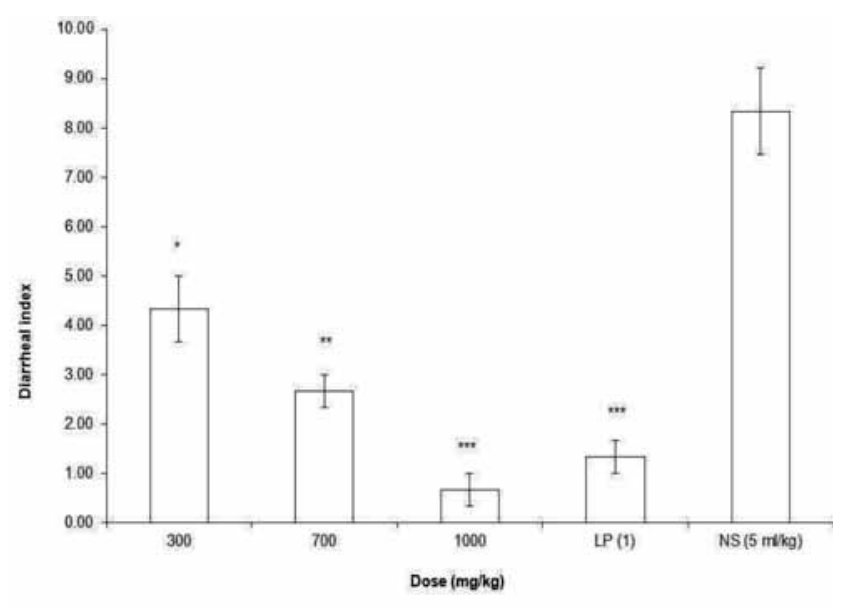

Figure-2: The protective effect of extract of Adansonia digitata (300-1000 mg/kg) on castor oil-induced diarrhoea in mice. Values are mean \pm S.E.M $* * * p<0.0001, * * p<$ 0.001 and $* * p<0.05$ show significant difference when compared with non-treated (normal saline) control group. to the untreated control mice. Similarly, at the dose of $300 \mathrm{mg} / \mathrm{kg}$, the extract produced significant $(\mathrm{p}<0.01)$ inhibition of diarrhoea caused by magnesium sulphate when compared with normal saline (untreated control). The extract produced an inhibition of diarrhoea caused by magnesium sulphate of between 36-75\% (Table-1).

Effect of A. digitata on castor oil-induced diarrhoea: The extract at doses of 300,700 and $1000 \mathrm{mg} / \mathrm{kg}$ protected the mice against castor oil-induced diarrhoea in a dose-dependent fashion (Figure-2).

The effect of $\boldsymbol{A}$. digitata on castor oil-induced enteropooling: The extract at oral doses of 300 and $700 \mathrm{mg} / \mathrm{kg}$ significantly $(\mathrm{p}<0.05)$ inhibited castor oil-induced enteropooling in rats, in addition, the extract at 1000 $\mathrm{mg} / \mathrm{kg}$ produced a more significant $(\mathrm{p}<0.01)$ inhibition of enteropooling caused by castor oil (Table-2). The standard drug, loperamide (5 mg/kg), also significantly inhibited $(\mathrm{p}<0.01)$ intestinal fluid accumulation produced by castor-oil.

\section{Discussion}

The significance of plants in medicine has led to several scientific and ethnopharmacological studies that resulted in the discovery of many pharmacological properties in plants [18]. Several studies have confirmed the biological effects attributed to medicinal plants and the best way to utilize them [19]. Most of the newer drugs that were discovered in the last few decades originated from natural sources [20]. The use of 
Table-2: Effect of the extract of Adansonia digitata on castor oil-induced enteropooling in rats $(n=5)$.

\begin{tabular}{lccc}
\hline Treatment & Dose $(\mathbf{m g} / \mathbf{k g})$ (oral) & Volume of intestinal fluid $(\mathbf{m l})$ (mean \pm S.E.M.) \\
\hline Normal saline & $5 \mathrm{ml} / \mathrm{kg}$ & $4.64 \pm 0.50$ & \% inhibition \\
Loperamide & 5 & $1.42 \pm 0.26^{* *}$ & - \\
$\begin{array}{ll}\text { A. digitata } \\
\text { A. digitata }\end{array}$ & 300 & $2.48 \pm 0.23^{*}$ & 2.40 \\
A. digitata & 700 & $2.08 \pm 0.21^{*}$ & 47.01 \\
\hline
\end{tabular}

$*=\mathrm{p}<0.05 ; * *=\mathrm{p}<0.01$, when compared with the non-treated (normal saline) control group.

phytochemical constituents and other natural products is currently on the increase towards the treatment of many diseases. Traditional medical practices have employed herbal remedies worldwide for the prevention and treatment of different diseases. Scientific research and clinical trials have confirmed the efficacy of several plants for the treatment and prevention of a number of diseases [21].

Diarrhoea is characterized by three or more watery loose stools in a 24-h period, or one or more stools, or bowel movement (gut motility) resulting in loss of fluids, electrolytes and nutrients [22]. In developing countries, where the standard of hygiene is poor, diarrhoea remains the leading cause of morbidity and mortality in all age groups in humans, with as many as four million cases occurring each year [23].

Different agents including bacteria, viruses, and parasites cause diarrhoea in food animal species. Many of these enteropathogens cause severe intestinal lesions, alterations in enzyme activity, alterations in nutrient transport mechanisms, or a combination of these effects. While most of these enteric agents cause diarrhoea, the clinical presentation varies. Some of the diarrhoeas are self-limiting, some are associated with high morbidity, and others are associated with high mortality [24].

In this study, the dried fruit methanol extract of $A$. digitata did not show any toxic effect on the mice as no death or behavioural change was recorded following oral administration of the extract even at $5 \mathrm{~g} / \mathrm{kg}$. As a standard, any substance that is not toxic at $\leq 5000 \mathrm{mg}$ / $\mathrm{kg}$ body weight is considered relatively safe [13].

The methanol extract of $A$. digitata at doses of 700 $\mathrm{mg} / \mathrm{kg}$ and $1000 \mathrm{mg} / \mathrm{kg}$ significantly $(\mathrm{p}<0.001)$ reduced the length traversed by charcoal meal in the gastrointestinal tract of mice. Similarly, the extract attenuated the severity of castor oil-induced diarrhoea in a dosedependent manner. The liberation of ricinoleic acid from castor oil results in irritation and inflammation of the intestinal mucosa, leading to release of prostaglandins, which stimulate gastrointestinal motility and secretion [25]. Furthermore, castor oil alters intestinal absorption causing decreased permeability of dissolved food and also the histology of the gastro-intestinal (GI) mucosa; that allows increased fluid loss across intestinal epithelial cells [25]. These findings indicate that the extract inhibits castor oil-induced diarrhoea and enteropooling. The effect of the extract at doses of $1000 \mathrm{mg} / \mathrm{kg}$ is similar to that of loperamide (standard antidiarrhoeal agent). It is possible that the extract reverses the pathological changes induced by castor oil.

The diarrhoeagenic effect of magnesium sulphate results from effects on gut smooth muscle (enhancement of transit) and mucosal electrolyte transport [26]. The inhibition of electrolyte absorption or stimulation of secretion causes the accumulation of fluid in the gut lumen [27].

Phytochemical screening of the extract revealed the presence of carbohydrates, glycosides, saponins, flavonoids, tannins, steroids and triterpenes. Flavonoids and sugars obtained from some local medicinal plants in some parts of the world exhibit antidiarrhoeal properties [28]. The leaves of Terminalia superb was shown to possess antidiarrhoeal activity because of the presence of tannin, alkaloid, saponins, flavonoids, sterol and triterpenes [29]. Flavonoids were shown to have the ability to attenuate the contraction of guinea pig ileum induced by some spasmogens [30]; they also have the ability to inhibit small intestinal transit [31]. Also astringents such as tannins have been known to have antisecretory activity in the gastrointestinal tract; hence they are used to treat diarrhoea [32]. In addition, tannin-containing drugs are widely used for the treatment of diarrhoea and related disorders [33,34]. Standard chemical tests used in this study revealed the presence of tannins in $A$. digitata which probably contributes to its antidiarrhoeal activity. Similarly, alkaloids, flavonoids, saponins as triterpenes are present in the fruit extract of $A$. digitata. Perhaps one or more of these chemical constituents may be responsible for the observed antidiarrhoeal/anti-spasmodic activity of $A$. digitata.

\section{Conclusion}

From the present study, it can be concluded that the methanol extract of the fruit of $A$. digitata contains compound(s) with antidiarrhoeal property. This finding supports its use in the traditional management of diarrhoea. However, further studies are needed in order to understand the mechanism of its antidiarrhoeal action and also to identify the bioactive component(s) of the extract. In addition, detailed toxicity studies are required to justify its clinical use.

\section{Authors' contributions}

MMS, IH and SG designed the study and collected materials for the experiments. MMS, MM and MUK drafted and revised the manuscript. MMS and PIK guided the research work. All authors read and approved the final manuscript.

\section{Acknowledgements}

All technical staff of the Departments of 
Veterinary Physiology, Pharmacology and Toxicology and Pharmacology and Therapeutics, Ahmadu Bello University are thanked for their technical assistance. The authors are thankful to Ahmadu Bello University for fund and facilities provided for this study.

\section{Competing interests}

The authors declare that they have no competing interests.

\section{References}

1. Forsberg, B., Petzold, M., Tomson., G. and Allebeck, P. (2007) Diarrhoea case management in low- and middleincome countries - an unfinished agenda. Bul. World Hlth Org. 85: 42-48.

2. Njume, C. and Goduka, N.I. (2012) Treatment of Diarrhoea in Rural African Communities: An Overview of Measures to Maximise the Medicinal Potentials of Indigenous Plants. Int. J. Environ. Res. Public Hlth. 9: 3911-3933.

3. Gutiérrez, S.P., Sánchez, M.A.Z., González, C.P. and García, L.A. (2007) Antidiarrhoeal activity of different plants used in traditional medicine. Afr. J. Biotechnol. 6: 2988-2994.

4. Rogé, J., Baumer, P., Bèrard, H., Schwartz. J.C. and Lecomte JM (1993) The enkephalinase inhibitor, acetorphan, in acute diarrhoea: a doubleblind, controlled clinical trial versus loperamide. Scand. J. Gastroenterol. 28: 352-354.

5. Salazar, E., Santisteban, J., Chea, E. and Gutierrez, M. (2000) Racecadotril in the treatment of acute watery diarrhoea. N. Engl. J. Med. 343: 463-467.

6. Snyder, J.D. and Mason, H.H. (1982) The magnitude of the global problem of acute diarrhoeal disease: A review of active surveillance data. Bull. Wrld. Hlth. Org. 60: 605-615.

7. Yusha'u M., Hamza, M.M. and Abdullahi, N. (2010) Antibacterial activity of Adansonia digitata stem bark extracts on some clinical bacterial isolates. In. J. Biomed. Hlth. Sci. 6: 129-135.

8. Kamatou, G.P.P., Vermaak, I. and Viljoen, A.M. (2011) An updated review of Adansonia digitata: A commercially important African tree. S. Afr. J. Bot. 77: 908-919.

9. Kaboré, D., Sawadogo-Lingani, H., Diawara, B., Compaoré, C.S., Dicko, M.H. and Jakobsen, M. (2011) A review of baobab (Adansonia digitata) products: Effect of processing techniques, medicinal properties and uses. Afr. J. Food Sci. 5: 833-844.

10. Musila, M.F., Dossaji, S..F., Nguta, J.M., Lukhoba, C.W. and Munyao, J.M. (2013) In vivo antimalarial activity, toxicity and phytochemical screening of selected antimalarial plants. J. Ethnopharmacol. 146: 557-561.

11. Offiah, N.V., Makama, S., Elisha, I.L., Makoshi, M.S., Gotep, J.G., Dawurung, C.J., Oladipo, O.O., Lohlum, A.S. and Shamaki, D. (2011) Ethnobotanical survey of medicinal plants used in the treatment of animal diarrhoea in Plateau State, Nigeria. BMC Vet. Res. 7: 36-44.

12. Tiwari P., Kumar, B., Kaur, M., Kaur, G. and Kaur, H. (2011) Phytochemical screening and Extraction: A Review. Internationale Pharmaceutica Sciencia 1:98-106.

13. Lorke, D. (1983) A new approach to practical acute toxicity testing. Arch. Toxicol. 54: 275-287.

14. Tembhurne, S.V. and Sakarkar, D.M. (2010). Acceleratory effect of Murraya koenigii leaves extracts in atropine induced delayed small intestinal transit involved possible cholinergic innervation in mice. Int. J. PharmTech Res. 2: 322-326.

15. Doherty, S.S. (1981) Inhibition of arachidonic acid release mechanism by which glucocorticoids inhibit endotoxin- induced diarrhoea. Brit. J. Pharmacol. 73: 549-554.

16. Vogel, H.C. and Vogel, W.H. (1997) Drug discovery and evaluation. Pharmacological assays. Berlin, Springer, p757.

17. Robert, A., Nezamis, J.E., Lancaster, C., Hanchar, A.J. and Klepper, M.S. (1976) Enteropooling assay, a test for diarrhoea produced by prostaglandins. Prostagladins 11: 809-828.

18. Dias, D.A., Urban, S. and Roessner, U. (2012) A Historical Overview of Natural Products in Drug Discovery. Metabolites 2:303-336.

19. Kinghorn, A.D., Pan, L., Fletcher, J.N. and Chai, H. (2011) The relevance of higher plants in lead compound discovery programs. J. Nat. Prod. 74: 1539-1555.

20. Newman, D.J. and Cragg, G.M. (2007) Natural products as source of new drugs over the last 25 years. J. Nat. Prod. 7: 461-477.

21. Suleiman, M.M., Romanus, I. and Yusuf, S. (2007) Gastroprotective effect of the crude methanol extract of Terminalia avicennioides in rats. Vet. Arhiv 77: 345-354.

22. Pacheco, G.D., Christen, A., Arnold, B., Hattendorf, J., Colford, J.M., Smith, T.A. and Mäusezahl, D. (2011). Reporting diarrhoea through a vernacular term in quechuaspeaking settings of rural Bolivia. J. Hlth. Popul. Nutr. 29: 552-559.

23. Farthing, M.J.G. (2002) Novel targets for the control of secretory diarrhoea. Gut 50: 15-18.

24. Luna, C.V.H. (2008). Calves and Characterization of Virulence Genes in Escherichia coli Isolated from Diarrhoeic and Healthy Neonatal calves in Austria. PhD thesis, University of Veterinary Medicine Vienna, Austria, p98.

25. Gaginella, T.S. and Phillips, S.F. (1975) Ricinoleic acid: Current view of an ancient oil. Digest. Dis. 20:1171-1177.

26. Inayathulla, Shariff, W.R., Karigar, A.A., Sikarwar, M.S. (2010) Evaluation of antidiarrhoeal activity of Crateva nurvala root bark in experimental animals. Int. J. Pharm. Pharm. Sci.2: 158-161.

27. Izzo, A.A., Gaginella, T.S., Mascolo, N. and Capasso, F. (1994) Nitric oxide as a mediator of the laxative action of magnesium sulphate. Br. J. Pharmacol. 113: 228-232.

28. Palombo, E.A. (2006) Phytochemicals from traditional medicinal plants used in the treatment of diarrhoea: modes of action and effects on intestinal function. Phytother. Res. 20: 717-724.

29. Bamisaye, F.A., Odutuga, A.A., Minari, J.B., Dairo, J.O., Fagbohunka, B.S. and Oluba, O.M. (2013). Phytochemical constituents and antidiarrhoeal effects of the aqueous extract of Terminalia superba leaves on Wistar rats. Afr. J. Pharm. Pharmacol. 7: 848-851.

30. Hejazian, S.H., Bagheri, S.M., Dashti-R, M.H. (2013) Relaxant effect of Humulus lupulus extracts on isotonic rat's ileum contractions. Avicenna J. Phytomed. 4: 53-58.

31. Khoshnazar, S.M., Bahaoddini, A. and Najafipour, H. (2013) Effect of alcoholic extract of licorice (Glycyrrhiza glabra 1.) rhizome on isolated duodenum motility in male rats and its interference with cholinergic, nitrergic, and adrenergic systems. Bull. Env. Pharmacol. Life Sci. 2: 173-177.

32. Ashok, P.K. and Upadhyaya, K. (2012) Tannins are astringent. J. Pharmacog. Phytochem. 1:45-50.

33. Friedman, L.S. and Isselbacher, K.J. (1998) Diarrhoea and constipation. In: Harrison's Principles of Internal Medicine, $14^{\text {th }}$ edition McGraw-Hill, New York, p236-242.

34. Brunton, L.L. (1996) Agents for control of gastric acidity and treatment of Peptic ulcers. In: Goodman and Gilman's the Pharmacological Basis of Therapeutics, $9^{\text {th }}$ edition. New York McGraw-Hill, p901-915. 